\title{
Molecular Phylogenetic Analysis of Turbo brunneus (R.1798), Cypraea annulus (L.1758) and Babylonia spirata (L.1758)
}

\author{
P. Subavathy \\ PG and Research Department of Zoology, St.Mary’s College (Autonomous), Affiliated to Manonmaniam Sundaranar University, India
}

Received December 2, 2019; Revised March 20, 2020; Accepted March 28, 2020

Copyright $\bigcirc 2020$ by authors, all rights reserved. Authors agree that this article remains permanently open access under the terms of the Creative Commons Attribution License 4.0 International License

\begin{abstract}
Over the past few decades, biologists from many disciplines have turned to phylogenetic analyses to interpret variation in biological systems. Phylogenetic relationships with a high potential in the absence of sufficient morphological characters can be resolved by molecular phylogenetic techniques according to coded characters. A number of mtDNA genes have been targeted in marine gastropods for phylogenetic purpose; these include the ribosomal RNA genes $28 \mathrm{~S}, 18 \mathrm{~S}, 16 \mathrm{~S}$ and $12 \mathrm{~S}$, Cytochrome oxidase I (COI) and cytochrome b (Cyt-b). In the present study, SSU rRNA in Turbo brunneus, $18 \mathrm{~S}$ rRNA in Cypraea annulus and COI gene in Babylonia spirata were successfully amplified and sequenced. Phylogenetic tree of the three species were constructed by using neighbor-joining tree. The optimal tree with the sum of branch length $=1.47445020$ was observed. Turbo brunneus was phylogenetically closer to the clade of Cypraea annulus than that of Babylonia spirata. The mitochondrial genomes are informative for mollusc phylogeny, which give a proper phylogenetic approach.
\end{abstract}

Keywords Gastropods, DNA Sequencing, SSU rRNA, $18 \mathrm{~S}$ rRNA, COI, Phylogeny

\section{Introduction}

Marine bioresource is known to be one of the richest among all the living ecosystems. Life originated in the sea and in terms of evolution and biodiversity the sea appears to be superior to the terrestrial ecosystem [1]. As marine species comprise approximately a half of the global biodiversity, they are offering a vast source from which useful therapeutics can be discovered. Ocean exploration often leads to new ideas, new theories and discoveries, including new medicines. The phylum mollusca has a long geological history and their presence on planet earth since the Paleozoic era 600 million years ago has been proved beyond doubt. The class gastropoda is known to have originated during the Jurassic era. Among the invertebrates, Phylum Mollusca is the second largest groups next to Arthropoda [2].

The phylum Mollusca encompasses seven classes, namely Gastropoda, Polyplacophora, Cephalopoda, Bivalvia, Scaphopoda, Aplacophora and Monoplacophora [3]. Among the seven classes, gastropods are highly diversified in shape, coloration, distribution, habitat and show tremendous adaptive radiation. Species of gastropoda with their ornamental shell and succulent meat have been harvested since time immemorial [4]. The majority of the gastropods belong to the subclass prosobranchia that includes all the gastropods that respire by means of gills and in which the mantle cavity, gill and anus are located at the anterior of the body. Also, most carnivorous gastropods are marine prosobranchs. The three orders which make up this subclass of prosobranchia are the oldest archaeogastropoda, the least specialized mesogastropoda, and the largest order, with particularly diverse in mode of life, and the specialized carnivores, the neogastropoda. Increased awareness and importance of chank genetic resources has turned attention back to the speciation and need to have scientific data on the genetic diversity of selected gastropod for species description and planning their conservation and management [5]. Shells of gastropod contain a rich source of taxonomic information that can be used to interpret evolutionary relationships among taxa [6]. However, literatures pertaining to economic characters and genetics on marine molluscs are scanty [7].

The progressive information have diverted the attention of the genetic workers to the techniques based on genomic as well as mitochondrial DNA. Nowadays DNA barcoding 
is an established technique that involves sequencing gene segments and comparing the results with orthologous reference sequences in public database [8].

The goal of DNA barcoding is to identify the sample species by sequencing a single gene that is universally amplified across metazoans using as template genetic materials isolated from a small portion of organisms in any state of their life unique barcode sequence, or by a tight cluster of very similar sequences [9].

DNA barcoding can be applied to several fields, including biodiversity monitoring (e.g. taxonomic, ecological and conservation studies) and forensic science. Additionally, it can be used to identify organisms that lack distinctive morphological features in the larval stage [10] or because of homoplasty and phenotypic plasticity of a given diagnostic character to environmental factors [11]. Moreover, DNA barcodig could be used to monitor the illegal trade of wildlife, such as protected or endangered species to identify the species origin of commercially processed foods [12].

Phylogenetic relationships among different organisms are of fundamental importance in biology and one of the prime objectives of DNA sequence analysis in phylogeny reconstruction for understanding evolutionary history of living organisms [13]. Unfortunately, the early hope that molecular data would provide the final word in vetting phylogenetic relationships has not yet been realized for many diverse, conspicuous and well-studied groups, including mollusca. This phylum represents a unique challenge in understanding the relatedness of several equally disparate clades and this topology therefore remains unresolved. Mitochondrial gene arrangements of gastropods exhibit high levels of variability are apparently rich in characters and may provide invaluable information for phylogenetic reconstruction. At present, the taxonomic status and the phylogenetic relationships of these species are still in dispute. More and more molecular markers are used to infer phylogenetic relationships among the gastropoda (Mollusca) based on DNA and RNA sequences [14]. Phylogenetic relationships with a high potential in the absence of sufficient morphological characters can be resolved by molecular phylogenetic techniques according to coded characters [15]. The nucleotide divergence between sequences of one gene or a portion of gene from the mitochondrial or nuclear genome can be analyzed phylogenetically.

Despite the increasing use of molecular methods to determine evolutionary relationships among taxa, only few molecular sequences data have been used to assess the relationship among the gastropods. A new type of information provided by molecular tool can now be used to clarify the relationships among the gastropods. Hence an attempt has been made to study the molecular phylogenetic analysis of the three marine gastropods Turbo brunneus, Cypraea annulus and Babylonia spirata.

\section{Materials and Methods}

In the present study the gastropods Turbo brunneus, Cypraea annulus and Babylonia spirata were collected from the Gulf of Mannar coastal region of Thoothukudi. The freshly collected samples were brought to the laboratory, cleaned and washed with fresh sea water to remove all impurities. The shells were broken, tissues were removed and then preserved in 95\% Ethanol.

\subsection{DNA Isolation, Amplification and Sequencing}

Ethanol - preserved samples of $T$. brunneus, C. annulus and B. spirata were re-hydrated in sterile double filtered water for atleast $2 \mathrm{~h}$ before extraction. $1 \mathrm{gm}$ of tissue sample was ground with mortar and pestle using $1 \mathrm{ml}$ of extraction buffer. $0.5 \mathrm{ml}$ of $10 \%$ SDS and $200 \mu \mathrm{l}$ of $5 \mathrm{M}$ $\mathrm{NaCl}$ were added and mixed well and incubated at $50^{\circ} \mathrm{C}$ for half an hour. To the mixture $250 \mu 1$ of phenol, $240 \mu 1$ of chloroform and $10 \mu \mathrm{l}$ of isoamyl alcohol at the ratio of $250: 240: 10$ were added. Mixed well and centrifuged at $12,000 \mathrm{rpm}$ for 10 minutes at $4^{\circ} \mathrm{C}$. The aqueous phase was collected in new eppendorf tubes and 0.2 volume of $1 \mathrm{M}$ ammonium acetate and 2 volume of ethanol were added and mixed well. The mixture was centrifuged at 10,000 rpm for 10 minutes at $4{ }^{\circ} \mathrm{C}$ and pellets were collected. To the pellet $700 \mu 1$ of $70 \%$ ethanol was added, mixed well and it was centrifuged for $5000 \mathrm{rpm}$ for 5 minutes at $4^{\circ} \mathrm{C}$. The pellets were air dired and $50 \mu \mathrm{l}$ of $1 \mathrm{X}$ TE buffer was added and stored at $-20^{\circ} \mathrm{C}$. DNA quality and quantity were determined by $0.8 \%$ agarose gel electrophoresis. DNA fragments were visualized by exposing the gel to ultraviolet light in a Transilluminator. The partial region of the genes SSU rRNA in Turbo brunneus, 18S rRNA in Cypraea annulus and cytochrome c oxidase subunit I (COI) gene in Babylonia spirata were amplified by PCR. The primers used for amplification of the SSU rRNA gene were 5'-CTGGTTGATCCTGCCAGT-3' [16] and 5'TAATGATCCTTCCGCAGGTTCACCT-3' [17]. The primers used for the amplification of the gene 18S rRNA were 5'-CCTGGTTGATCCTGCCAG-3' and 5'TAATGATCCTTCCGCAGGTTA-3' [18]. The primers used for the amplification of the gene COI were 5'-GGTCAACAAATCATAAAGATATTGG-3' and 5'TAAACTTCAGGGTGACCAAAAAATCA-3' [19]. A 1.0 $\mu \mathrm{l}$ of sample DNA (approximately $100 \mathrm{ng} / \mu \mathrm{l}$ ) was added to PCR reaction mixture containing $100 \mathrm{mM}$ Tris $\mathrm{HCl}(\mathrm{pH}$ 8.3), $500 \mathrm{mM} \mathrm{KCl}$ (pH 8.3), $2.0 \mu \mathrm{lgCl}_{2}(25 \mathrm{mM}), 2.0 \mu \mathrm{l}$ dNTP's $(2.5 \mathrm{mM}), 1.0 \mu \mathrm{l}$ forward and reverse primers (each of $10 \mathrm{pm} / \mu \mathrm{l}), 1 \mathrm{u} / \mu \mathrm{l}$ of Taq DNA polymerase and $25 \mu \mathrm{l}$ nuclease free water. The PCR was performed in ABI Veriti 96 Well-Thermal Cycler (Applied Biosystems). PCR amplification condition consisted of an initial denaturation at $95^{\circ} \mathrm{C}$ for $2 \mathrm{~min}$, followed by 35 cycles: denaturation at $95^{\circ} \mathrm{C}$ for $30 \mathrm{sec}$, annealing at $56^{\circ} \mathrm{C}$ for $30 \mathrm{sec}$, extension at $72^{\circ} \mathrm{C}$ for $40 \mathrm{sec}$ and a final extension at $72^{\circ} \mathrm{C}$ for $5 \mathrm{~min}$. An additional extension step at $72^{\circ} \mathrm{C}$ for 1 min was added. The 
PCR products were separated by electrophoresis in $2 \%$ agarose gel containing ethidium bromide $\left(1 \mu \mathrm{g} \mathrm{ml}^{-1}\right)$. The correct size band was excised from $2 \%$ low melting point agarose in TAE buffer. The amplified products were visualized under ultra-violet light in a transilluminator and documented. PCR products were purified with QIAquick PCR Purification Kit and sequenced using ABI 3130 Genetic Analyzer with BigDye Terminator Cycle Sequencing Kit v3.1 (Applied Biosystems). The sequence data generated was initially analyzed by using Sequencing Analysis (Applied Biosystems) Software for further use.

\subsection{Sequence Analysis}

Multiple sequence alignment and pairwise sequence alignment were performed using Clustal W program implemented in MEGA 6.0 in all the sequences. The amplified sequences belonging to DNA barcode region of SSU rRNA in $T$. brunneus, $18 \mathrm{~S}$ rRNA in C. annulus and $\mathrm{COI}$ in $B$. spirata were confirmed by percent similarity in the NCBI's BLAST program. Higher percentage similarity $(95-100 \%)$ against the reference sequence was used to confirm the identity of the species. All the sequences were submitted to the NCBI's Genbank through BankIt according to NCBI's procedure with required information.

\subsection{Phylogenetic Tree Construction Using MEGA}

The phylogenetic trees were constructed using the neighbor-joining method [20] in MEGA6 [21]. The data were bootstrapped 500 times to estimate the internal stability of each node. For the analysis of the phylogenetic relationships, sequences of representatives of the Turbinidae, Cypraeidae and Babyloniidae were obtained from GenBank.

\section{Results}

DNA barcoding region of SSU rRNA in Turbo brunneus, 18S rRNA in Cypraea annulus and COI gene in Babylonia spirata were successfully amplified. The bands of size 250bp and 700bp were observed in T. brunneus, 300bp and $560 \mathrm{bp}$ were observed in C. annulus and 290bp and 650bp were observed in B. spirata (Figure 1). The sequences of about 906 bases were observed in T. brunneus, 312 bases were reported in $C$. annulus and 549 bases were observed in B. spirata. In T. brunneus, C. annulus and B. spirata samples of about 9,5 and 8 sequences showed significant alignments of which the maximum identity ranged from $99 \%$ to $100 \%, 98 \%$ to $100 \%$ and $96 \%$ to $100 \%$. The maximum score ranged from 1674 to 1561 in T. brunneus, 577 to 536 in C. annulus and 1014 to 904 in B. spirata respectively. The query coverage was found to be $100 \%$ in T. brunneus, $C$. annulus and B. spirata respectively. All the submitted sequences were assigned accession numbers by Genbank. The accession numbers are KY766259, KU665620 and KU665621.

Phylogenetic tree of the three species were constructed by using neighbor-joining tree. The optimal tree with the sum of branch length $=1.47445020$ is shown in Figure 2 . Topologically two major clades were formed, one major clade comprising 13 species and the next clade comprising of only one species. Turbo brunneus was phylogenetically closer to the clade of Cypraea annulus than that of Babylonia spirata. The genus and species level discrimination can be ascertained by strong bootstrap support of over $99 \%$. Throughout the tree, several clades have moderate $(>50 \%)$ to high $(>70 \%)$ levels of bootstrap support.

Marker

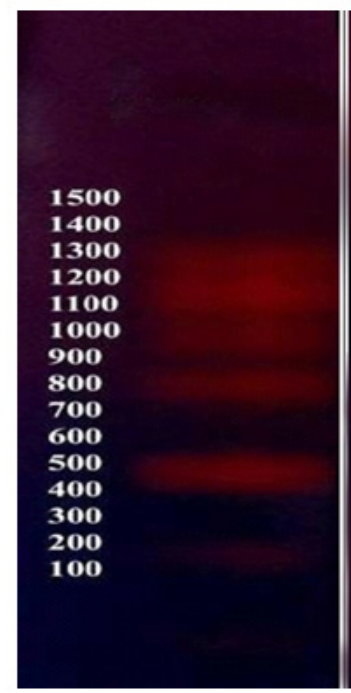

Lane 1 - Turbo brunneus

Lane 2 - Cypraea annulus

Lane 3 - Babylonia spirata
Lane 1
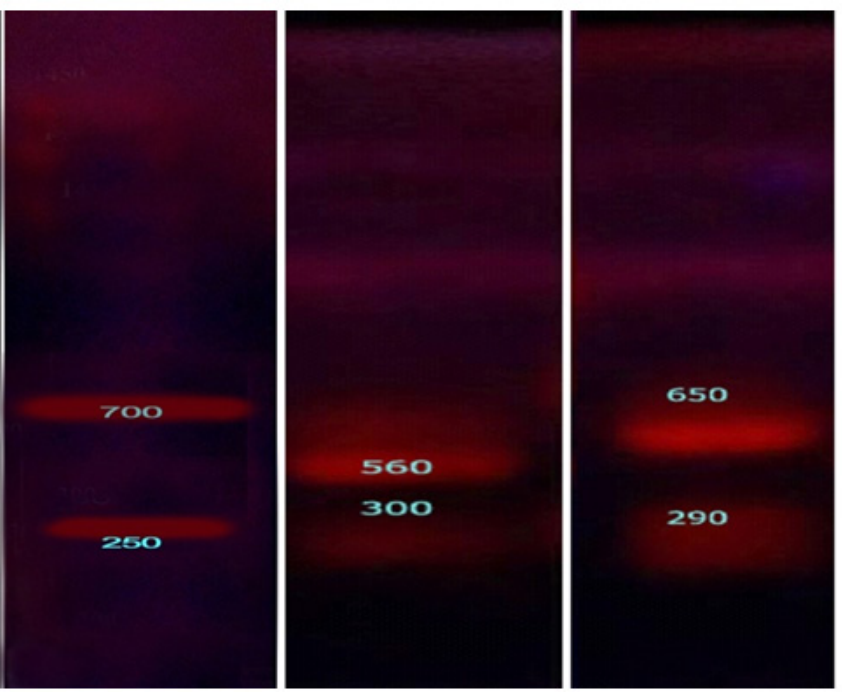

Figure 1. Agarose gel electrophoresis image of PCR product 


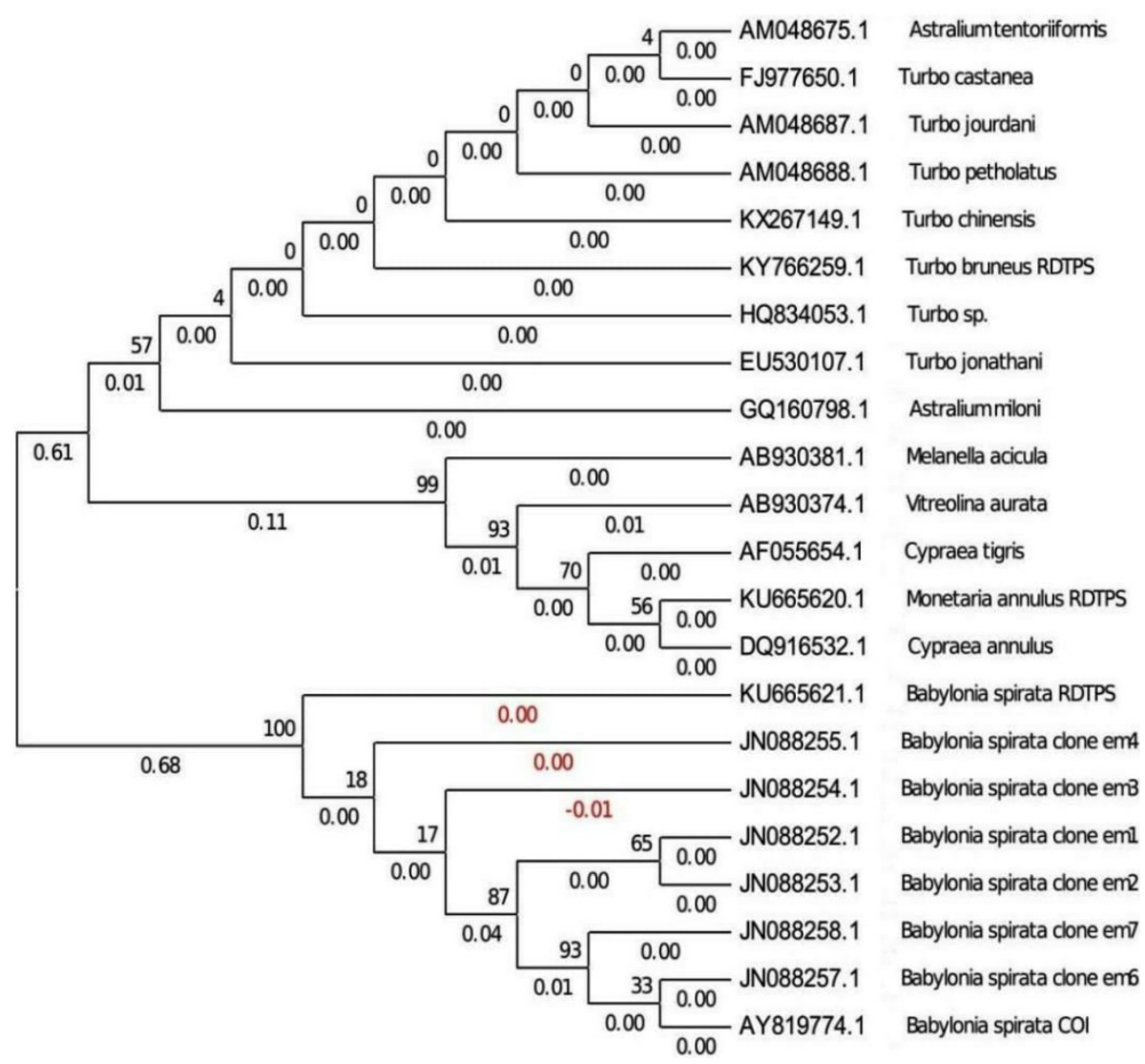

Figure 2. Neighbor-Joining phylogenetic tree with branch lengths and bootstrap value

\section{Discussion}

Molecular identification of species through the analysis of a small fragment of the genome represents a more promising approach for species identification, and is already accepted among scientists. The approach consists of amplification and sequencing of a specified 'barcode region', followed by comparison of the recovered sequence to available genetic databases to determine species identity [8]. The utility of barcodes can be limited by overlap of genetic variation between closely related species $[22,23]$ and by the lack of reference sequences in existing genetic databases [24]. New approaches to accelerate the taxonomic analysis of molluscan samples are critically needed and DNA barcoding provides a number of particular advantages and opportunities. To date, most marine barcoding studies have been designed to discriminate species of a particular taxonomic group [25]. Costa et al. [26] showed that the mtCOI barcode region was $95 \%$ successful in classifying species to the correct order. Remigio and Hebert [27] found evidence of resolution of the recognized subclasses of gastropod molluses using mtCOI.

In the present study DNA barcoding region of SSU rRNA in Turbo brunneus, 18S rRNA in Cypraea annulus and COI gene in Babylonia spirata were successfully amplified. 18S rRNA is very conservative gene and has therefore been suggested as a phylogenetic marker to trace the relationships among distantly related taxa [18]. COI sequence analysis (termed DNA barcoding) has been suggested as a tool for the identification of species [28] and holds potential to aid in the discrimination of new species [29]. Kaneko et al. [30] reported the sequence divergence of shallow water octopuses at the COI and COII loci.

Wilding et al. [31] determined partial mtDNA sequences of the prosobranch gastropod Littorina saxatilis, and they demonstrated that mitochondrial gene arrangements are highly variable not only among different molluscan classes, but also within the class gastropoda. Kurabayashi and Ueshima [32] described the complete sequence 14,189bp of the mtDNA of opisthobranch gastropod Pupa strigosa. The mitochondrial gene arrangement of Pupa strigosa is almost identical to those of pulmonate land snails but is different from those of the prosobranch gastropod Littorina saxatilis and other molluscs. As the gene arrangement of opisthobranch and pulmonate gastropods are lying closer these species are showing close phylogenetic affinity. The present study agrees well with the above findings. The bands of size $250 \mathrm{bp}$ and $700 \mathrm{bp}$ were observed in $T$. brunneus, $300 \mathrm{bp}$ and $560 \mathrm{bp}$ were observed in $C$. annulus and 290bp and 650bp were observed in B. spirata.

Matsumoto and Hayami [33] reported the genetic relationship among $S$. broughtonii, S. satowi, S. subcrenata, Diluvarca tricenicosta and Tegillarca granosa in Japan, $A$. 
antiquata in Philippine and T. nodifera in China based on 302 amino acid sequences of the mtDNA COI gene. The neighbor-joining tree formed a monophyletic clade with Scapharca, Diluvarca, Anadara and Tegillarca. Yasunori Kano et al. [34] analyzed the nucleotide sequences and large ribosomal molecule (28S rRNA) of eight neritopsine species and three outgroup species. The ingroup species were drawn from all the six extant families of the superorder recognized by Ponder [35] i.e. Neritopsidae, Titiscaniidae, Hydrocenidae, Helicinidae, Phaenacolepadidae and Neritidae as well as from Neritiliidae, the family regarded as a distinct clade by recent morphological studies [36]. Similarly, Lee and Kim [37] reported genetic differentiation among the bivalves $S$. broughtonii, S. satowi and S. subcrenata based on a 599bp portion of the mtDNA COI gene. In the present investigation the sequences of about 906 bases were observed in T. brunneus, 312 bases were reported in $C$. annulus and 549 bases were observed in B. spirata.

Aranishi and Okimoto [38] studied nucleotide sequence polymorphism in a $641 \mathrm{bp}$ novel major noncoding region of mitochondrial DNA of the Pacific oyster Crassostrea gigas. The phylogenetic studies were performed for wild and cultured populations of $C$. gigas by PCR-RFLP analysis of the cytochrome oxidase c subunit I gene [39] and by nucleotide sequence analysis of both the COI and $16 \mathrm{~S}$ rRNA genes [40]. Aguilera et al. [41] noticed the Japanese abalone $H$. discus hannai is closely related to the California abalone species ( $H$. fulgens, $H$. corrugata and $H$. cracherodii). Additionally, Oliverio et al. [42] analyzed ITS2 sequences in distinct gastropod species and the genus Stramotina and Concholepas (Rapaninae) are found to be closely related to Nucella (Ocenebrinae). Remigio and Hebert [43] reported a phylogenetic analysis using COI sequences with different gastropod species, concluding that the Thais genus is evolutionarily close to the Nucella genus. This work supports the findings of the present study. Turbo brunneus was phylogenetically closer to the clade of Cypraea annulus than that of Babylonia spirata.

Xiangzhi et al. [44] described the phylogeny of the cuttle fishes based on mitochondrial COI and 16S rRNA gene sequence data. $\mathrm{NJ}$ trees of $\mathrm{COI}$ and amino acid of COI gene supported that sepiolidae and sepiidae belong to the sister groups, the bootstrap values were all below $50 \%$. Very similar to the present study Liana Jannotti-Passos et al. [45] studied the phylogenetic analysis of Biomphalaria tenagophila. B. tenagophila and B. glabrata were located in the same branch. However, both are more closely related with opisthobranchia than with other pulmonata, supported by high bootstrap values (98\% and $100 \%)$. Tanaka and Aranishi [46] showed a monophyletic clade including Scapharca, Anadara and Tegillarca using a neighbor-joining tree. The nucleotide and amino acid sequences of the mtDNA COI gene indicated a monophyletic clade of closely related genera that belong to Anadarinae. Journey et al. [47] reported the phylogenetic tree with 13-protein encoding $\mathrm{mt}$ gene sequences of Physella acuta. Tony Kess et al. [48] described the DNA extraction and sequences from a family of ten Littorina saxatilis. Uribe et al. [49] studied the phylogenetic relationships of four extant superfamilies Neritopsoidea, Hydrocenoidea, Helicinoidea and Neritoidea. In the present study, the phylogenetic tree derived from SSU rRNA, 18S rRNA and COI gene sequences showed that the genus Turbo had a closer relationship with the genus Cypraea.

\section{Conclusions}

Molluscs represent an important and highly diverse group of animals. Many species are of particular interest to humans as food and medicine. The inclusion of molluscs in the burgeoning field of comparative genomics is therefore prudent from both practical and evolutionary perspectives. The results of the present study, reveals that phylogenetic relationship of Turbo brunneus was closer to the clade of Cypraea annulus than that of Babylonia spirata. Two decades ago, phylogenetic methods were rarely used except by systematists with a basic interest in the evolutionary history of life. Today, those methods are widely used in biomedical applications, in molecular investigations of genome organization, gene structure and in all fields.

\section{REFERENCES}

[1] Macdougall JD. A short history of planet earth, John wiley Eds, New York, 5, 1996.

[2] Abbott RT. American Sea Shells The marine mollusc of Grand Cayman Island, Monogr, Acad. Natur. Sci., Philadelphia, 11: 117, 1954.

[3] Brusca RC and Brusca GJ. Invertebrados, Guanabara Koogan, Rio de Janeiro, 1098, 2007.

[4] Leiva EG and Castilla JC. A review of the world marine gastropod fishery: Evolution of catches, management and the chilean experience. Rev. Fish Boil. Fislr., 11:283 - 300, 2002.

[5] Hodbay AJ and Tegner MJ. Status review of white abalone (Halotis sorenseni) throughout its range in California and Mexico. NOAA Tech Memor. NMFS-SWR-035: 90, 2000.

[6] Chiu YW, Chen HC, Lee SC and Chen CA. Morphometric analysis of shell and operculum variations in the Viviparid snail, Cipangopaludina chinensis (Mollusca: Gastropoda), in Taiwan. Zool. Stud., 41(3): 321 - 331, 2002.

[7] Knowlton N. Molecular genetic analyses of species boundaries in the sea. Hydrobiologia, 420: 73 - 90, 2005.

[8] Hebert PDN, Cywinska A, Ball SL and deWaard JR. Biological identifications through DNA barcodes. Proc. R. 
Soc. Lond B, 270: 313 - 321, 2003a.

[9] Ward RD, Zemlak TS, Innes BH, Last PR and Hebert PDN. DNA barcoding Australia's fish species. Phil. Trans. R. Soc. Lond B, 360: 1847- 1857, 2005.

[10] Pegg GG, Sinclair B, Briskey L and Aspden WJ. mtDNA barcode identification of fish larvae in the Southern Great Barrier Reef, Australia. Sci. Mari., 70: 7 - 12, 2006.

[11] Vences M, Thomas M, Bonett RM and Vieites DR. Deciphering amphibian diversity through DNA barcoding: chances and challenges. Phil. Trans. Roy. Soc B, 360: 18591868, 2005.

[12] Tanabe S, Miyauchi E, Muneshige A, Mio K, Sato C and Sato M. PCR method of detecting pork in foods for verifying allergen labeling and for identifying hidden pork ingredients in processed foods. Biosci. Biotechnol. Biochem., 71: 1663 $-1667,2007$.

[13] Chaudhri P and Das S. Statistical analysis of large DNA sequences using distribution of DNA words. Curr. Sci., 80(9): 1161 - 1166, 2001.

[14] Grande C, Templado J and Cervera JL. Molecular phylogeny of Euthyneura (Mollusca: Gastropoda). Mol. Biol. Evol., 21: $303-313,2004$.

[15] Ryan AT. Using 18S rDNA to resolve diaptomid copepod (Copepoda: Calanoida: Diaptomidae) phylogeny: An example with the North American genera. Hydrobiologia, 519: 135 - 141, 2004.

[16] Hillis DM and Dixon MT. Ribosomal DNA: molecular evolution and phylogenetic inference. Q. Rev. Biol., 66: 411 $-453,1991$.

[17] Halanych KM, Lutz RA and Vrijenhoek RC. Evolutionary origins and age of vestimentiferan tube worms. Cah. Biol. Mar., 39: 355 - 358, 1998.

[18] Winnepenninckx B, Backeljau T and Steiner G. Details of gastropod phylogeny inferred from $18 \mathrm{~S}$ rRNA sequences. Mol. Phylogen. Evol., 9: 55 - 63, 1998.

[19] Folmer O, Black M, Hoeh W, Lutz R and Vrijenhoek R. DNA primers for amplification of mitochondrial cytochrome C oxidase subunit I from diverse metazoan invertebrates. Mol. Mar. Bio. Biotechnol., 3: 294 - 299, 1994.

[20] Nei M and Kumar S. Molecular evolution and phylogenetics. Oxford University Press, New York, 333, 2000.

[21] Tamura K, Stetcher G, Peterson D, Filipski A and Kumar S. MEGA6: Molecular Evolutionary Genetics Analysis version 6.0. Mol. Biol. Evol., 30: 2725 - 2729, 2013.

[22] Meyer CP and Paulay G. DNA barcoding: error rates based on comprehensive sampling. PLoS Biol., 3: e422. doi: 10.1371/journal.pbio.0030422, 2005.

[23] Monaghan MT, Balke M, Gregory TR and Volger AP. DNA based species delineation in tropical beetles using mitochondrial and nuclear markers. Phil. Trans. R. Soc. Lond B. Biol. Sci., 360: 1925 - 1933, 2005.

[24] Darling JA and Blum MJ. DNA-based methods for monitoring invasive species: a review and prospectus. Biol. Inva., 9: $751-765,2007$.
[25] Bucklin A, Hopcroft RR, Kosobokova KN, Nigro LM, Ortman BD, Jennings RM, Sweetman CJ. DNA barcoding of Arctic Ocean holozooplankton for species identification and recognition. Deep Sea Research II. doi: 10.1016/j.dsr2.2009.08.005, 2009.

[26] Costa FO, deWaard JR, Boutillier J, Ratnasingham S, Dooh RT, Hajibabaei $M$ and Hebert PDN. Biological identifications through DNA barcodes: the case of the Crustacea. Can. J. Fish Aqua. Sci., 64: 272 - 295, 2007.

[27] Remigio EA and Hebert PDN. Testing of utility of partial COI sequences for phylogenetic estimates of gastropod relationships. Mol. Phylogen. Evol., 29: 641 - 647, 2003.

[28] Hebert PDN, Stoeckle MY, Zemlak TS and Francis CM. Identification of birds through DNA barcodes. PLoS Biol., 2: e 312, 2004.

[29] De Salle R, Egan MG and Siddall M. The unholy trinity: taxonomy, species delimitation and DNA barcoding. Phil. Trans. R. Soc. Lon B. Biol. Sci., 360: 1905 - 1916, 2005.

[30] Kaneko N, Kubodera T and Iguchi A. Taxonomic study of shallow-water octopuses (Cephalopoda: Octopodidae) in Japan and adjacent waters using mitochondrial genes with perspective on octopus DNA barcoding. Malacologia, 54: 97 $-108,2011$.

[31] Wilding CS, Mill PJ and Grahame J. Partial sequence of the mitochondrial genome of Littorina saxatilis: relevance to gastropod phylogenetics. J. Mol. Evol., 48: 348 - 359, 1999.

[32] Kurabayashi A and Ueshima R. Complete sequence of the mitochondrial DNA of the primitive opisthobranch gastropod Pupa strigosa: systematic implication of the genome organization. Mol. Biol. Evol., 17(2): 266 - 277, 2000 .

[33] Matsumoto M and Hayami I. Molecular phylogenetics and taxonomic characters of the Anadarinae (Bivalvia). Fossils, 69: $25-34,2001$

[34] Yasunori Kano, Satoshi Chiba and Tomoki Kase. Major adaptive radiation in neritopsine gastropods estimated from 28S rRNA sequences and fossil records. Proc. R. Soc. Lond B, 269: $2457-2465,2002$.

[35] Ponder WF. Superorder Neritopsina In Mollusca: The Southern Synthesis: Fauna of Australia. (ed.P.L.Bees-ley, G.J.B.Ross and A.Wells) Melbourne, Australia, CSIRO, 5: $693-702,1998$.

[36] Kano Y and Kase T. Anatomy and systematics of the submarine-cave gastropod Pisulina (Neritopsina, Neritiliidae). J. Moll. Stud., 68 (4): 365 - 384, 2002.

[37] Lee SY and Kim SH. Genetic variation and discrimination of Korean ark shell Scapharca species (Bivalvia, Arcoida) based on mitochondrial COI gene sequences and PCR-RFLP. Korean J. Gen., 25(4): 309 - 315, 2003.

[38] Aranishi F and Okimoto T. Sequence polymorphism in a novel noncoding region of Pacific oyster mitochondrial DNA. J. Appl. Genet., 46(2): 201 - 206, 2005.

[39] Boudry P, Heurtebise S, Collet B, Cornette F and Gerard A. Differentiation between populations of the Portuguese oyster, Crassostrea angulata (Land mark) Pacific oyster, Crassostrea gigas (Thunberg), revealed by mtDNA RFLP analysis. J. Exp. Mar. Biol. Ecol., 226: 279 - 291, 1998. 
[40] Boudry P, Heurtebise S and Lapegue S. Mitochondrial and nuclear DNA sequence variation of presumed Crassostrea gigas and Crassostrea angulata specimens: a new oyster species in Hong Kong? Aquaculture. 228 (1-4): 15 - 25, 2003.

[41] Aguilera F, Lafarga F and Gallardo-Escarate C. Molecular analysis in Chilean commercial gastropods based on $16 \mathrm{~S}$ rRNA, COI and ITS 1-5.8S rDNA - ITS2 sequences. Gayana, 73(1): $17-27,2009$.

[42] Oliverio M, Cervelli $M$ and Mariottini P. ITS2 rRNA evolution and its congruence with the phylogeny of muricid neogastropods (Caenogastropoda, Muricoidea). Mol. Phylo. Evol., 25: $63-69,2002$.

[43] Remigio EA and Hebert PDN. Testing of utility of partial COI sequences for phylogenetic estimates of gastropod relationships. Mol. Phylogen. Evol., 29: 641 - 647, 2003.

[44] Xiangzhi L, Zheng XD, Shu X and Wang R. Phylogeny of the cuttlefishes (Mollusca: Cephalopoda) based on mitochondrial COI and 16S rRNA gene sequence data. Act. Oceanol. Sin., 23(4): 699-707, 2004.
[45] Liana Jannotti-Passos K, Jeronimo Ruiz C, Roberta Caldeira L, Silvane Murta MF, Paulo Marcos Coelho Z, Omar Carvalho S. Phylogenetic analysis of Biomphalaria tenagophila (Orbigny,1835) (Mollusca: Gastropoda). Mem. Inst. Oswaldo Cruz, 105(4): 504 - 511, 2010.

[46] Tanaka T and Aranishi F. Mitochondrial DNA markers for PCR-based phylogenetic analysis of ark shells. J. Mar. Sci., 3: $182-189,2013$

[47] Journey RN, Ulfar Bergthorsson and Adema CM. Physella acuta: a typical mitochondrial gene order among panpulmonates (Gastropoda). J. Moll. Stud., 80: 388 - 399, 2014.

[48] Tony Kess, Jeffrey Gross, Fiona Harper and Boulding EG. Low-cost ddRAD method of SNP discovery and genotyping applied to the periwinkle Littorina saxatilis. J. Moll. Stud., 82: $104-109,2016$.

[49] Uribe JE, Colgan D, Castro LR, Kano Y and Zardoya R. Phylogenetic relationships among superfamilies of Neritimorpha (Mollusca: Gastropoda). Mol. Phylogenet. Evol., 104: 21 - 31, 2016. 